\title{
Ryles Tube Knotting around the Tracheal Tube: Twin-Magills Forceps to our Rescue!
}

\author{
Uma Hariharan*, Nikhil Bhasin, Alka Gupta Nihar Nalini Senapati and Koninica Sanyal \\ Department of Anesthesia and Intensive care, Dr Ram Manohar Lohia Hospital, India
}

Submission: February 05, 2017; Published: April 06, 2017

*Corresponding author: Dr. Uma Hariharan (MBBS, DNB, PGDHM, Fellowship Oncoanaesthesia), Assistant Professor Anaesthesia and Intensive care, Dr Ram Manohar Lohia Hospital and Post Graduate Institute of Medical Education and Research, Central Health Services, BH 41 East shalimar Bagh, New Delhi 110088, India, Tel: 9811271093; Email: uma1708@gmail.com

\begin{abstract}
Ryles' tube is generally inserted by anaesthesiologists in the peri-induction period for gastric decompression and other intra- and postoperative uses by the surgeons. It can be inserted both before and after induction. In addition, either the nasal or oral route can be chosen for their introduction. When inserted nasally after endotracheal intubation, its path can be deflected by the presence of the oral part of the tracheal tube. Ryles' tube insertion is associated with several complications like nasal or oropharyngeal bleeding, soft tissue trauma, infection, coiling, inability to enter the pharyngeal opening, esophageal perforation and nose-to-mouth migration. Coiling of the ryles' tube around the endotracheal tube can occur, leading to knot formation, which can be difficult to unwind. We hereby describe an uncommon complication of ryles' tube insertion and its management.
\end{abstract}

Keywords: Ryles' tube; Endotracheal tube; Knotting; Magill's' forceps

\section{Introduction}

Ryles' tube insertion [1] is usually done in the perioperative period for gastric decompression and for other intra-and postoperative use by the surgeons. Its insertion is generally blind and may be fraught with several minor and major complications. In difficult cases, gastric tube insertion can be guided by direct laryngoscopy [2] or video-laryngoscopy, if available. Apart from trauma, bleeding, [3] coiling and unsuccessful insertion, there are a few reports of its inadvertent knotting around the endotracheal tube. This complication, though uncommon, can be dangerous. We hereby report a case of accidental ryles' tube knotting around the endotracheal tube and its successful unwinding using Magills' forceps.

\section{Case Report}

A fifty-four year old, ASA grade 2, male patient was scheduled for radical cystectomy with ileal conduit for carcinoma bladder under standard general anaesthesia. After induction and endotracheal intubation, a nasogastric tube (NG tube) was introduced into the right nostril after lubrication. After a while, there was resistance to its insertion and the ryles' tube could not be advanced into the esophagus. A direct laryngoscopy was performed to visualise the path of the nasogastric tube. The NG tube was found to be coiled around the oral part of the endotracheal tube (ETT), with the formation of a spontaneous knot. Trying to withdraw the NG tube would have been risky as it can lead to accidental tube displacement or extubation, apart from trauma and bleeding. Untying of the knot is difficult inside the oral cavity with the endotracheal tube in-situ, as there is less space to work, along with the risk of tube obstruction from further tightening of the knot. Hence, we had two mammoth tasks in this patient. One was to untie the knot and the second was to uncoil the loops of the NG tube around the ETT, both without compromising the airway and patient safety.

With an independent anaesthesiologist performing direct laryngoscopy, the second anaesthesiologist utilized two Magills' forceps, one pediatric and the other adult, held on each hand to first untie the knot. Tip of the NG tube was held by the pediatric forceps on the left hand and the right hand-held adult forceps was used to loosen the loop, so that the distal tip comes out of the loop. After untying the knot successfully, the left hand was used to tightly hold the oral part of the endotracheal tube. The right hand-held forceps were used to gently uncoil the loops of the NG tube around the ETT, one-by-one. After both untying and uncoiling, the NG tube was smoothly removed from the right nostril and the nasal-oral cavity inspected for any bleeding or trauma (Figure 1). The entire procedure was uneventful, with no complications. The patient maintained all vital parameters 
within normal limits. The ETT position was found to be in place and the patient was ventilated adequately. A fresh NG tube was successfully inserted gently through the left nostril after adequate nasal preparation. The rest of the perioperative course was uneventful.

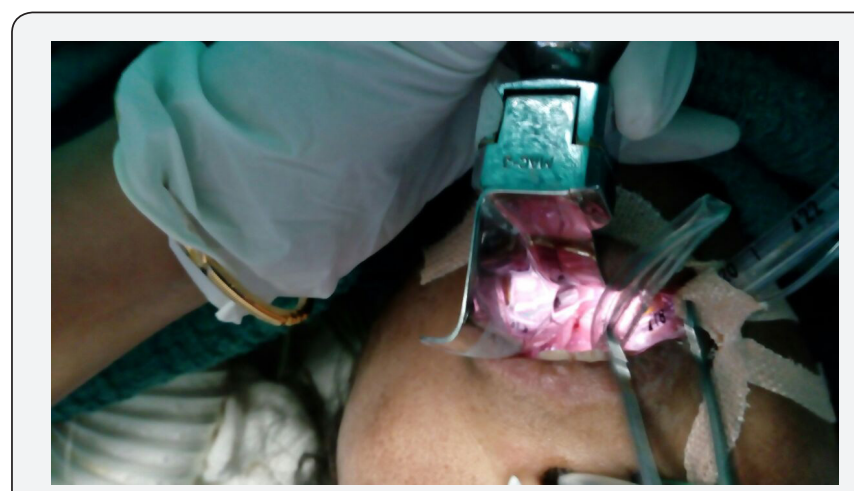

Figure 1: Picture showing uncoiling of ryles tube from the endotracheal tube using Magills forceps.

\section{Discussion}

Our case highlights that a simple task of inserting an NG tube can be complicated [4] with both common and uncommon problems. Knotting and coiling of the NG tube around the ETT is a known, though rare complication [5]. It can prove deleterious to the patient, as it can lead to airway compromise. Such coiled and knotted tubes should never be pulled out forcefully, as it can lead to ET tube displacement, ET tube obstruction [6] accidental extubation and loss of airway. Such disastrous complications can be avoided by gentle unwinding of the knot followed by the loops under vision. Magills' forceps is very useful in such scenarios. The first step in the wake of such complications is to promptly recognise its presence and take necessary action immediately, after calling for help. Our case was unique, as we had used two Magills' forceps for the procedure.There have been a few case reports highlighting the use of a Magills forceps [7] for this complication. Use of direct laryngoscopy or videolaryngoscopy (if available), is recommended to proceed under vision. C-MACTM D-blade video laryngoscope [8] is particularly useful in this regard.

Gentle handling of the tube and tissues is paramount is avoiding bleeding and trauma. ETT displacement must be prevented at all costs. Standard ASA monitoring must be continued and patient safety should be given top-most priority.

\section{Conclusion}

Nasogastric tube insertions can be sometimes complicated by their coiling and knotting around the endotracheal tube, if inserted after intubation. Inadvertent pulling out of such coiled NG tubes can result in accidental tube displacement, extubation and trauma. The use of twin-Magills forceps can be advantageous in untying the knot and uncoiling the NG tube from the ETT. Gentle manoeuvring must be applied to prevent traumatic and other complications.

\section{References}

1. Tanguy M, Seguin P, Mallédant Y (2007) Bench-to-bedside review: Routine postoperative use of nasogastric tube - utility or futility? Crit Care 11(1): 201.

2. Ching YH, Socias SM, Ciesla DJ, Karlnoski RA, Camporesi EM, et al. (2014) The difficult intraoperative nasogastric tube intubation: A review of the literature and a novel approach. Sage Open Med 2: 205312114524390.

3. Joseph TT, Shenoy L, Harshan A, Shanmukhappa SM (2014) Rare complication of nasogastric tube insertion. Anesth Essays Res 8(1):118119.

4. Bautista EM (1988) Complications of nasogastric tube insertion. Chest 93: 1119-1120.

5. Acharya G, Arora KK, Kumar D (2014) Nasogastric tube coiled around endotracheal tube. J Anaesthesiol ClinPharmacol 30(4): 584-586.

6. Pousman RM, Koch SM (1997) Endotracheal tube obstruction after orogastric tube placement. Anesthesiology 87(5): 1247-1248.

7. Au-Truong X, Lopez G, Joseph NJ, Salem MR (2000) A case of a nasogastric tube knotting around a tracheal tube: Detection and management. AnesthAnalg 89(6): 1583-1584.

8. Shah SB, Hariharan U, Bhargava AK (2016) C Mac D blade: Clinical tips and tricks. Trends in Anaesthesia and Critical Care 6: 6-10.

\section{Your next submission with Juniper Publishers} will reach you the below assets

- Quality Editorial service

- Swift Peer Review

- Reprints availability

- E-prints Service

- Manuscript Podcast for convenient understanding

- Global attainment for your research

- Manuscript accessibility in different formats ( Pdf, E-pub, Full Text, Audio)

- Unceasing customer service

Track the below URL for one-step submission https://juniperpublishers.com/online-submission.php 